\title{
Adaptive Capacity on Flexible Learning in the New Normal: The Case of Davao Del Norte State College
}

\author{
Arnold M. Duping, $\mathrm{PhD}^{1}$; Ronald S. Decano, $\mathrm{PhD}^{2}$; Jevannel G. Borlio ${ }^{3}$ \\ ${ }^{l}$ Dean, Institute of Teacher Education, Davao del Norte State College, Philippines \\ ${ }^{2}$ Dean of Institute of Advanced Studies, Davao del Norte State College, Philippines \\ ${ }^{3}$ Faculty, Institute of Teacher Education, Davao del Norte State College, Philippines
}

\begin{abstract}
This study aims to investigate the adaptive capacity of the students and faculty members of Davao del Norte State College in the new teaching and learning modalities demanded by this new normal setting. With the CoViD-19 pandemic lurking into the academic grounds, posing new challenges, the researchers initiated to describe the academic profile of the $\mathbf{2 5 4 7}$ students and 109 faculty members. Results revealed that utilizing television and transistor radio devices on blended learning may not be effective due to a huge number of learners who will not be able to access learning materials delivered through these media. Moreover, 1148 of 2290 students described not having Internet connection at home. Yet, on the status of Internet connectivity, only 67 learners have no Internet access in their area. Fourteen (14) faculty members revealed not having Internet Connection at home, but was able to gain access during the physical duty schedules. This result suggests that even without Internet Connection at home, students and faculty members are findings ways to cope with the learning and teaching challenges in these difficult times.
\end{abstract}

Keywords: COVID-19, New Teaching and Learning Modalities, Higher Education, Internet Connectivity, Blended Learning, Learning Management System

\section{INTRODUCTION}

A s cases of coronavirus (COVID-19) in the Davao Region rise, more and more provinces and municipalities have adopted shelter-in-place orders to curtail the pandemic. The disruption to most daily lives has been drastic and suddenand perhaps one of the most dramatic shifts was education system moving into the virtual settings (Vegas, 2020).

Because of the pandemic, the Philippine educational system experienced the herculean challenge of exploring other new learning modalities that will facilitate in the migration from traditional classes to flexible teaching and learning options (CHED CMO No. 04, 2020). In this new world of social distancing, higher education has become completely virtual, thus, poverty becomes stronger in most developing nations because many students cannot afford to buy the devices needed to attend to virtual classes. With all the financial limitations, both teachers and students experienced the barriers to access quality education. Each institution devised online learning models to serve as framework in this new way of delivering instruction, considering less experiences and fewer resources of all entities involved in the academic community.

Nevertheless, with the opening of the academic year 2020-
2021 of Davao del Norte State College with complete virtual operations of classes, different challenges were encountered by both teachers and students and digital divide was a concern that is pressing hard on the academic grounds (Cereno \& Borlio, 2021). Moreover, State Colleges cater students who are coming from provinces and municipalities with challenged status on Internet Connection. Although some of these spots already have mobile signals, the issue may arise in the description of the socioeconomic profiles of these students that are different from those who are enrolled in private schools. Thus, this inspired the researchers to assess the current status of the community on flexible learning with the hope of enhancing the adaptive capacity of the entire College in this new normal academic setting.

In addressing the gap in the conduct of this research, while the archives of the State College feature researches that focused on various academic concerns before the onset of this pandemic, this research endeavor is a novel case in employing blended teaching and learning setting adapted by faculty members and teachers in delivering instruction and complying with the academic requirements during health crisis. Thus, a compendium of literature related to the variables of interest was utilized for the methodologies and interpretations of the results.

\section{Objectives of the Study}

This study was conducted to describe the adaptive capacity of faculty members and students on blended teaching and learning. Specifically, the study sought to describe the academic profile of students in terms of institute, program and year level. Moreover, this study intends to describe the adaptive capacity of students in blended learning in terms of availability of electricity at home, availability of television at home, availability of transistor radio (AM/FM) at home, availability of Internet Connection at home, type of Internet connection used for virtual learning, devices available to use for learning, status of Internet connectivity, experienced learning modality, usage of DNSC LMS, features of DNSC LMS used, platforms utilized with teachers during synchronous sessions and platforms utilized with teachers during asynchronous sessions.

Meanwhile, this study also aimed to describe the academic profile of the faculty members in terms of institute, department, employment status and years in service. Finally, 
the paper intended to describe the adaptive capacity of faculty members in blended learning in terms of availability of Internet Connection at home, available type of Internet connection used for teaching online, devices available to use for teaching, status of Internet connectivity, usage of DNSC LMS, attendance on trainings related to flexible learning and trainings needed related to flexible learning.

\section{METHODOLOGY}

Comprehensive data was the target of this research paper with proposed complete enumeration technique (Passmore \& Baker, 2005) with all teaching personnel from all institutes. Students in all degree courses and all year levels were the target respondents. However, due to the short timeframe and the limited access to the Google Forms made accessible during the data collection phase, 2547 students and 109 faculty members were able to accomplish the survey questionnaires. Descriptive statistics was utilized for the data treatment in addressing the objectives set for this study.

\section{RESULTS AND DISCUSSION}

The responses of the students and faculty members on their academic profile and adaptive capacity on blended teaching and learning are presented and discussed in this section.

Table 1

\begin{tabular}{|c|c|c|c|}
\hline \multicolumn{4}{|c|}{ Academic Profile of Students in Terms of Institute } \\
\hline \multicolumn{2}{|c|}{ Institute } & Frequency & Percent \\
\hline $\begin{array}{c}\text { Graduate } \\
\text { School }\end{array}$ & 39 & 1.5 \\
\hline IAAS & 242 & 9.5 \\
\hline IED & 573 & 22.5 \\
\hline IIT & 575 & 22.6 \\
\hline IMAGOCS & 1118 & 43.9 \\
\hline Total & 2547 & 100.0 \\
\hline
\end{tabular}

Presented in Table 1 is the actual population of students who participated in the survey projecting each of the Institute of the College. Based on estimates, considering drop out with and without permission cases, this total number represents more than half of the total population of learners enrolled in the academic year of 2020-2021 during first semester. As much as the researchers wanted to collect all data from all students enrolled, sample representative has been an issue since online surveys can only cover a certain population (i.e., Internet users) (Callegaro, Manfreda, \& Vehovar, 2015). The survey does not contain the responses from non-Internet users or people who are less familiar with technology (Park, Park, Heo, \& Gustafson, 2019). Moreover, during the scheduled data collection phase, the possibilities that not all students were online are considered an important contributor to the final population sampled in this paper.
Table 2: Academic Profile of Students in Terms of Program

\begin{tabular}{|c|c|c|}
\hline Programs & Frequency & Percent \\
\hline $\begin{array}{c}\text { Bachelor of Science in Tourism } \\
\text { Management }\end{array}$ & 347 & 13.6 \\
\hline $\begin{array}{c}\text { Bachelor of Science in Information } \\
\text { Technology }\end{array}$ & 345 & 13.5 \\
\hline Bachelor of Science in Social Work & 234 & 9.2 \\
\hline $\begin{array}{c}\text { Bachelor of Science in } \\
\text { Entrepreneurship }\end{array}$ & 231 & 9.1 \\
\hline $\begin{array}{c}\text { Bachelor of Science in Information } \\
\text { Systems }\end{array}$ & 231 & 9.1 \\
\hline $\begin{array}{c}\text { Bachelor of Technology and } \\
\text { Livelihood Education }\end{array}$ & 203 & 8 \\
\hline $\begin{array}{c}\text { Bachelor of Science in Disaster } \\
\text { Resiliency and } \\
\text { Management }\end{array}$ & 155 & 6.1 \\
\hline $\begin{array}{l}\text { Bachelor of Secondary Education } \\
\text { major in English }\end{array}$ & 145 & 5.7 \\
\hline $\begin{array}{c}\text { Bachelor of Science in Marine } \\
\text { Biology }\end{array}$ & 111 & 4.4 \\
\hline $\begin{array}{c}\text { Bachelor of Secondary Education } \\
\text { major in } \\
\text { Mathematics }\end{array}$ & 94 & 3.7 \\
\hline Bachelor of Public Administration & 88 & 3.5 \\
\hline $\begin{array}{l}\text { Bachelor of Secondary Education } \\
\text { major in Sciences }\end{array}$ & 68 & 2.7 \\
\hline $\begin{array}{l}\text { Bachelor of Science in Fisheries and } \\
\text { Aquatic Sciences }\end{array}$ & 65 & 2.6 \\
\hline $\begin{array}{c}\text { Bachelor of Science in Food } \\
\text { Technology }\end{array}$ & 64 & 2.5 \\
\hline Bachelor of Arts in Communication & 47 & 1.8 \\
\hline $\begin{array}{c}\text { Master of Arts in Educational } \\
\text { Management }\end{array}$ & 43 & 1.7 \\
\hline $\mathrm{PhD}$ in Educational Management & 37 & 1.5 \\
\hline Bachelor of Science in Agroforestry & 17 & 0.7 \\
\hline $\begin{array}{c}\text { Master in Science Teaching - } \\
\text { Biology }\end{array}$ & 10 & 0.4 \\
\hline $\begin{array}{c}\text { Master in Science Teaching - } \\
\text { Mathematics }\end{array}$ & 9 & 0.4 \\
\hline $\begin{array}{c}\text { Master of Arts in Basic Education - } \\
\text { English Teaching }\end{array}$ & 2 & 0.1 \\
\hline MS in Marine Biodiversity & 1 & 0 \\
\hline Total & 2547 & 100.0 \\
\hline
\end{tabular}

Table 2 displays the actual count of students who were able to participate in the online survey, both from graduate and undergraduate groups projecting the 6 and 22 programs, respectively.

Table 3: Academic Profile of Students in Terms of Year Level

\begin{tabular}{|c|c|c|}
\hline Year Level & Frequency & Percent \\
\hline First Year & 934 & 36.7 \\
\hline Third Year & 836 & 32.8 \\
\hline Second Year & 677 & 26.6 \\
\hline Fourth Year & 86 & 3.4 \\
\hline Grad School & 14 & 0.5 \\
\hline Total & 2547 & 100.0 \\
\hline
\end{tabular}


It can be gleaned in Table 3 that the sampled population is highly represented by first year, third year and second year students comprising $36.7 \%, 32.8 \%$ and $26.6 \%$, respectively while the graduate level students only comprise the $0.5 \%$. The 86 count of fourth year students participating in the online survey may be influenced by the transition of the educational system to K-12 Curriculum wherein after three years in transition, it decreased the number of students in higher years, most especially in the undergraduate programs. More to this are other factors such as no Internet connectivity and pushpull of daily life experienced by graduating students (Yarbrough, Haas, Northam, Duke, \& Wieck, 2016).

Table 4: Adaptive Capacity of Students in Blended Learning

\begin{tabular}{|c|c|c|c|c|c|c|c|}
\hline \multirow[b]{2}{*}{ Category } & \multirow[b]{2}{*}{$\begin{array}{c}\text { Condition } \\
\mathrm{s}\end{array}$} & \multicolumn{5}{|c|}{ Year Level } & \multirow[b]{2}{*}{ Total } \\
\hline & & $1 \mathrm{st}$ & 2 nd & $3 \mathrm{rd}$ & 4th & $\begin{array}{c}\text { Grad } \\
\text { Scho } \\
\text { ol }\end{array}$ & \\
\hline \multirow{3}{*}{$\begin{array}{c}\text { Availabili } \\
\text { ty of } \\
\text { electricity } \\
\text { at } \\
\text { home }\end{array}$} & No & 16 & 9 & 18 & 2 & 0 & 45 \\
\hline & Solar & 2 & 3 & 1 & 0 & & 6 \\
\hline & Yes & 916 & 665 & 817 & 84 & 14 & 2496 \\
\hline \multirow{2}{*}{$\begin{array}{c}\text { Availabili } \\
\text { ty of } \\
\text { television } \\
\text { at home }\end{array}$} & No & 147 & 136 & 156 & 15 & 0 & 454 \\
\hline & Yes & 787 & 541 & 680 & 71 & 14 & 2093 \\
\hline \multirow{2}{*}{$\begin{array}{l}\text { Availabili } \\
\text { ty of } \\
\text { transistor } \\
\text { radio } \\
\text { (AM/FM) } \\
\text { at } \\
\text { home }\end{array}$} & No & 508 & 343 & 462 & 47 & 5 & 1365 \\
\hline & Yes & 426 & 334 & 374 & 39 & 9 & 1182 \\
\hline \multirow{2}{*}{$\begin{array}{c}\text { Availabili } \\
\text { ty of } \\
\text { Internet } \\
\text { connectio } \\
\mathrm{n} \text { athome }\end{array}$} & No & 399 & 317 & 416 & 45 & 1 & 1148 \\
\hline & Yes & 535 & 360 & 420 & 41 & 13 & 1369 \\
\hline
\end{tabular}

\begin{tabular}{|c|c|c|c|c|c|c|c|}
\hline & & & & & & & \\
\hline \multirow{2}{*}{$\begin{array}{c}\text { Status of } \\
\text { Internet } \\
\text { connectivity }\end{array}$} & Good & 202 & 157 & 165 & 18 & 8 & 550 \\
\cline { 2 - 8 } & Intermittent & 709 & 501 & 647 & 67 & 6 & 1930 \\
\cline { 2 - 8 } & No internet & 23 & 19 & 24 & 1 & 0 & 67 \\
\hline \multirow{7}{*}{$\begin{array}{c}\text { Learning } \\
\text { modalities }\end{array}$} & $\begin{array}{c}\text { Combinatio } \\
\text { nof modular } \\
\text { online and } \\
\text { online } \\
\text { learning }\end{array}$ & 492 & 364 & 426 & 57 & 4 & 1343 \\
\cline { 2 - 9 } & $\begin{array}{c}\text { Modular } \\
\text { online) }\end{array}$ & 332 & 257 & 348 & 23 & 0 & 960 \\
\cline { 2 - 9 } & $\begin{array}{c}\text { Modular } \\
\text { (printed) }\end{array}$ & 35 & 22 & 28 & 2 & 1 & 88 \\
\cline { 2 - 8 } & $\begin{array}{c}\text { Online } \\
\text { learning }\end{array}$ & 75 & 34 & 34 & 4 & 9 & 156 \\
\hline \multirow{2}{*}{$\begin{array}{c}\text { Usage of } \\
\text { DNSC LMS }\end{array}$} & No & 52 & 65 & 117 & 11 & 12 & 257 \\
\cline { 2 - 8 } & Yes & 882 & 612 & 719 & 75 & 2 & 2290 \\
\hline
\end{tabular}

Table 4 presents the adaptive capacity of students in the College in terms of availability of electricity, television, and transistor radio and Internet connection at home, status of the
Internet connectivity, the experienced learning modalities and the usage of the College's Learning Management System (LMS). The table shows the status of each category per year level, divided into different conditions. It can be apprehended that majority of the students are no longer living in remote areas where electricity is not available. Out of the total sampled population, only $1.8 \%$ live without electricity at home, which explains the instances that these students inform their teachers that they still need to ask their neighbors the favor of charging their mobile phones.

On the availability of television and transistor radio at home, those who answered No comprised $18 \%$ and 54\%, respectively, which suggest that utilizing these devices on blended learning may not be effective due to a huge number on learners who will not be able to access learning materials delivered through these modes. Interestingly, this resonates the result in one study conducted by Feruzi and $\mathrm{Li}$ (2020) in China, wherein the results revealed that the transition from classroom teaching and learning to teaching and learning through radio and television stations platform was not effective. The cited reason was on the demonstrated incompetence of the government in running and monitoring the program mostly in terms of preparation and implementation.

Moreover, while $45 \%$ of the students described not having Internet connection at home, on the status of Internet connectivity, only 67 learners have no Internet in their area. After closer examination of the data, it was found out that most of those who ticked No have altered their answers to intermittent or poor Internet connection status. Literature revealed that even before the onset of the pandemic, digital divide is pressing hard on developing nations like Philippines (Vishkaie, 2020). As pointed out, there are a number of factors that make it difficult for people to obtain access to the Internet. These include things such as poverty; high device, data, and telecommunications charges; infrastructure barriers; digital literacy challenges; and policy and operational barriers. These challenges represent significant barriers for millions of people in the developing world (Niyigena,, Jiang, Ziou, Shaw, \& Hasan, 2020).

Furthermore, Bryan and Volchenkova (2016) posited that blended learning has many definitions from various proponents. Accordingly, definitions might cover any instructional technology at all, or restrict themselves to webbased technology; they might not mention technology specifically, but instead focus on blending different theoretical approaches. The results revealed in Table 4 that the College generated its own definition of the term based on learning modalities used by learners, which is the combination of modular online, modular printed and online learning with the usage of College's learning management system. The nonusage of the LMS was due to other preferred platforms of teachers and the preferred pure modular printed learning modality brought by poor to no Internet connectivity of some learners. 


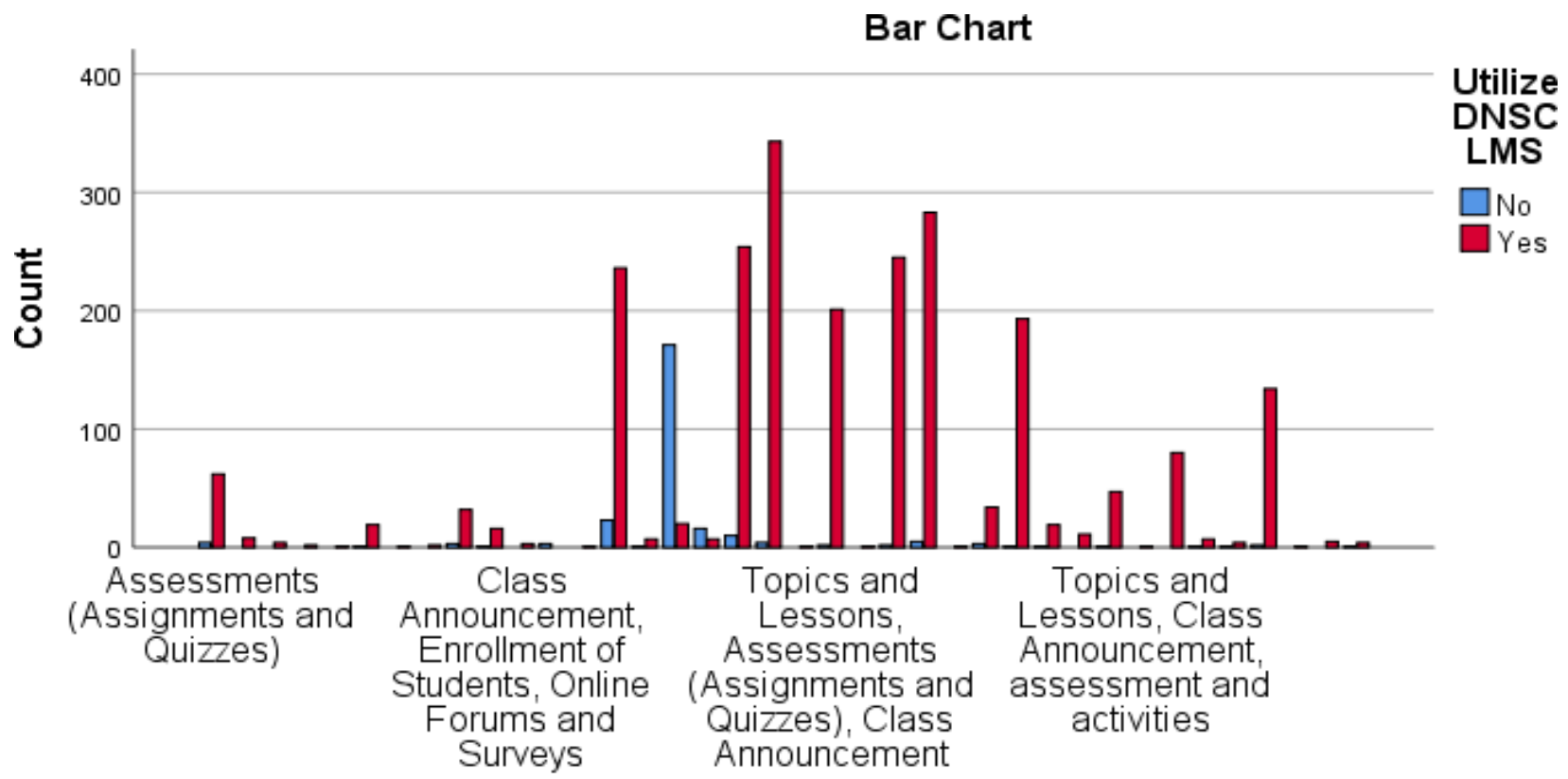

Feature Utilized LMS

Figure 1. Features of LMS commonly used by students in blending learning.

Among those who utilized the LMS, a combination of features of the platform were explored by students shown in Figure 1, which in summary comprised of assessments, assignments and quizzes, class announcements, enrollment, online forums and surveys, and topics and lessons. The initiative of the College to provide the teachers and learners with its own
LMS goes with the statement of Kabassi et al. (2016) that Learning Management Systems (LMSs) seem to offer a very good solution in choosing the best e-Learning platform, as they provide the instructors the capability of designing and administrate their courses as they want. In this way the blended learning is better supported.

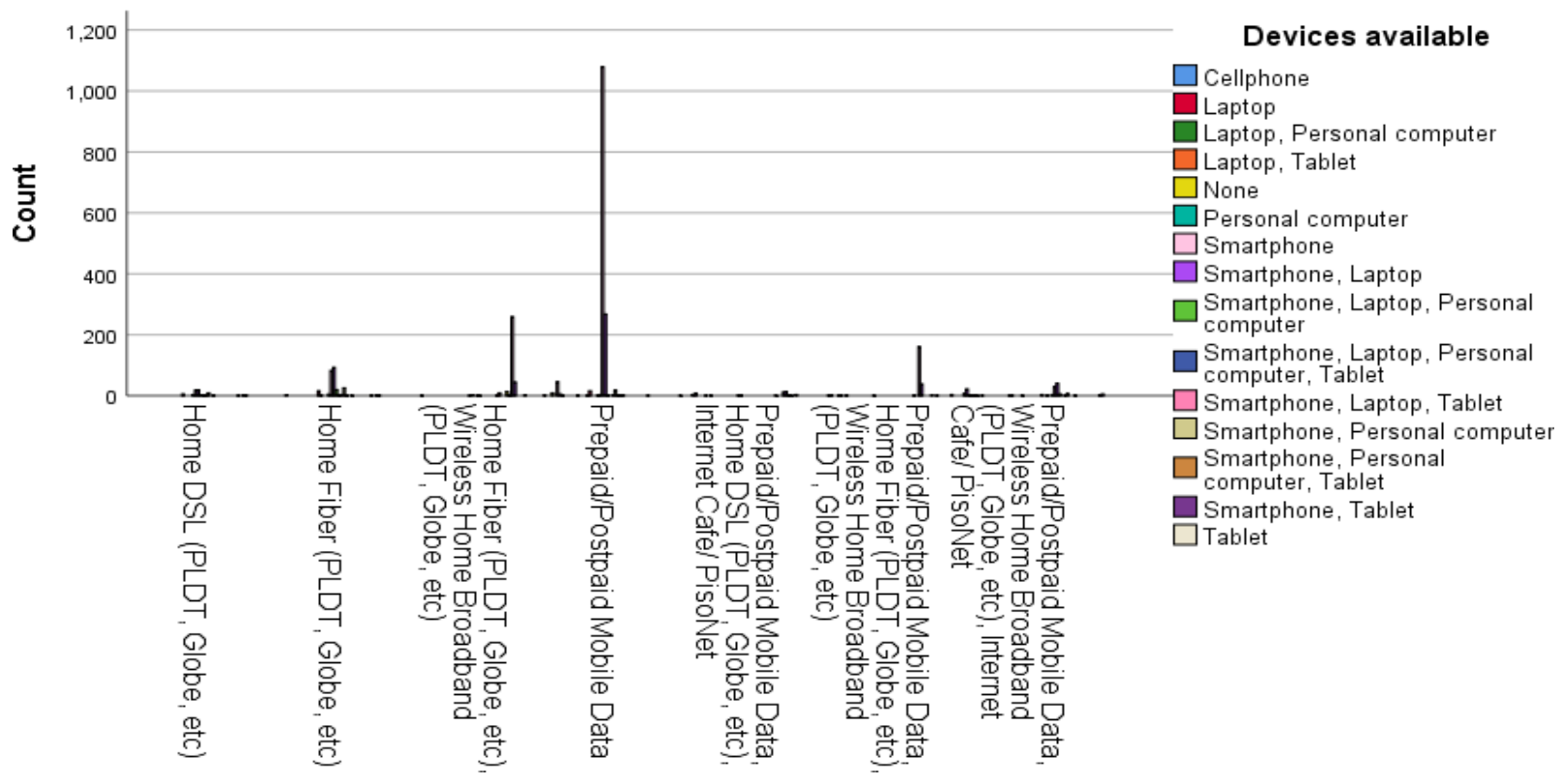

Figure 2. Type of Internet connection used for virtual learning and devices available to use

As presented in Figure 2, there are students who answered no devices used in online learning, yet some of them answered Internet Café and Pisonet on the type of Internet connection used. This somehow implies that the students took the initiative of going to these places, where they can access files posted online even without owning any device at home, 
especially when the lockdown protocols in their respective municipalities were lifted. While many Filipino students were using Internet cafes before as place to play online games (Reyes, 2020), now they are using it for online learning, which is actually also the case in Indonesia wherein minors are already allowed to enter the Internet cafés during class hours because students with no devices at home opt to use the cafés to do research in answering their supplemental materials or learning modules (Wibowo, Udasmoro, \& Noviani, 2020).

\section{Synchronous Learning}

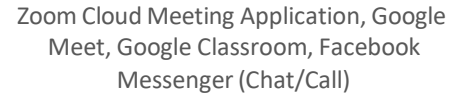

Zoom Cloud Meeting Application, Google Meet, Google Classroom, Facebook$$
\text { Messenger (Chat/Call) }
$$

Google Meet, Google Classroom, Facebook Messenger (Chat/Call)

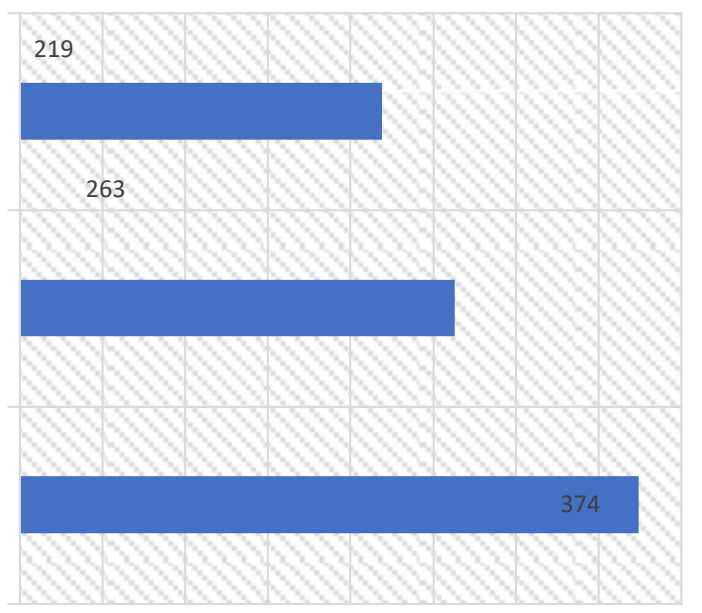

$\begin{array}{lllllllll}0 & 50 & 100 & 150 & 200 & 250 & 300 & 350 & 400\end{array}$

Figure 3: Platforms utilized with teachers during synchronous sessions.

With the announced free features of Google Meet, shown in Figure 3, this platform ranked as the top preferred by teachers to use in conducting synchronous teaching. Ranked the second and third are the combinations of various free platforms.

\section{Google Classroom}

DNSC-Learning Management System (DNSC-

LMS), Google Classroom, Facebook

Messenger (Chat/Call), Facebook

$$
\text { Group/Page }
$$

DNSC-Learning Management System (DNSC-

LMS), Google Classroom, Facebook

Messenger (Chat/Call), Facebook

Group/Page, Email

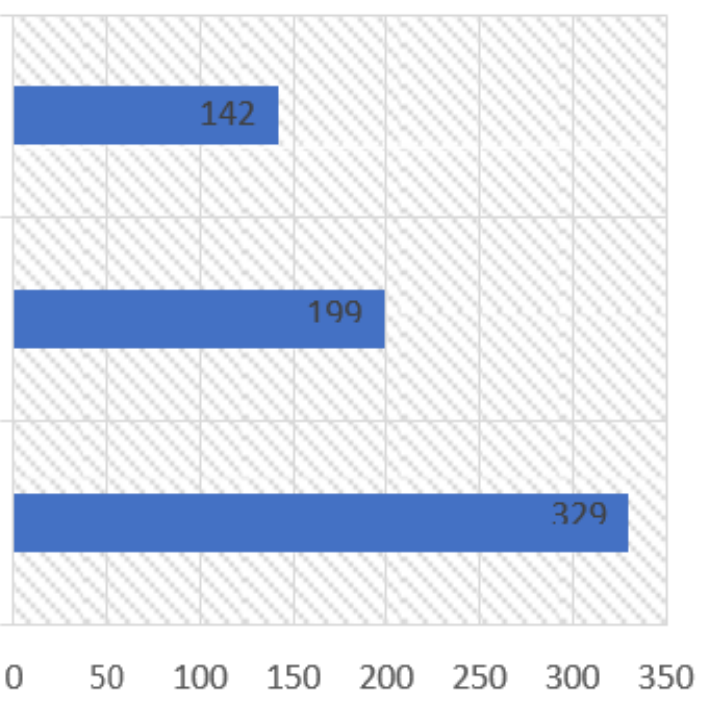

Figure 4: Platforms utilized with teachers during asynchronous sessions. 
Meanwhile, on the platforms used by teachers for students during asynchronous sessions, the combination of the LMS, Google Classroom, Facebook Messenger (Chat/Call), Facebook Group/Page and emails ranked the most utilized, which was also the case in the study conducted by Cereno and Borlio (2021), when they described the condition of teacher education, major in Sciences students, in their plight to this online learning set-up. As opined by Zayapragassarazan (2020), the pandemic forced the teaching community to think of new avenues and alternate strategies for engaging students, thus students are provided with a variety of choices for their learning and allows them to take more responsibility for their own learning.

Tables 5: Academic Profile of the Faculty Members

\begin{tabular}{|c|c|c|c|c|c|c|}
\hline \multicolumn{2}{|c|}{ Category } & IEd & IIT & IMAGoCS & IAAS & Total \\
\hline \multirow{18}{*}{ Department } & Tourism Management & 0 & 0 & 9 & 0 & 9 \\
\hline & TLE & 4 & 0 & 0 & 0 & 4 \\
\hline & Social Work & 0 & 0 & 4 & 0 & 4 \\
\hline & Social Sciences & 0 & 0 & 9 & 0 & 9 \\
\hline & Public Administration & 0 & 0 & 3 & 0 & 3 \\
\hline & Physical Education & 3 & 0 & 0 & 0 & 3 \\
\hline & Mathematics & 5 & 0 & 0 & 0 & 5 \\
\hline & Language & 11 & 0 & 0 & 0 & 11 \\
\hline & $\begin{array}{l}\text { Information } \\
\text { Technology }\end{array}$ & 0 & 12 & 0 & 0 & 12 \\
\hline & Information Systems & 0 & 7 & 0 & 0 & 7 \\
\hline & Fisheries & 0 & 0 & 0 & 2 & 2 \\
\hline & Entrepreneurship & 0 & 0 & 9 & 0 & 9 \\
\hline & DRM & 0 & 0 & 8 & 0 & 8 \\
\hline & Agroforestry & 0 & 0 & 2 & 0 & 2 \\
\hline & Science & 9 & 2 & 0 & 0 & 11 \\
\hline & Professional Education & 5 & 0 & 0 & 0 & 5 \\
\hline & Marine Biology & 0 & 0 & 0 & 1 & 1 \\
\hline & Food Technology & 0 & 0 & 0 & 4 & 4 \\
\hline \multirow{4}{*}{$\begin{array}{l}\text { Employment } \\
\text { Status }\end{array}$} & Permanent & 18 & 11 & 16 & 7 & 52 \\
\hline & Temporary & 9 & 3 & 7 & 0 & 19 \\
\hline & Contract of Service & 5 & 6 & 15 & 0 & 26 \\
\hline & Part Time & 5 & 1 & 6 & 0 & 12 \\
\hline \multirow{4}{*}{ Year ofService } & $0-10$ years & 27 & 13 & 42 & 3 & 85 \\
\hline & $11-20$ years & 1 & 3 & 1 & 1 & 6 \\
\hline & 21-30 years & 7 & 5 & 0 & 1 & 5 \\
\hline & $31-40$ years & 2 & 0 & 1 & 2 & 5 \\
\hline
\end{tabular}

After the data collection phase, 109 faculty members from Institutes of Education, Information Technology, Management Governance and Continuing Studies, and Aquatic and Applied Sciences were able to respond to the Google form. These teachers also represented the 18 departments with almost half of them having permanent employment status. On the length of service, these pool of faculty members are crowded by $79 \%$ of the population who rendered 0-10 years with the longest year of 39 years by one of the senior faculty.

With varied field of specialty and interest, educational expertise, employment status and length of years of service, it is interesting to explore the adaptive capacity of these mentors maneuvering the delivery of instruction in the college's new academic setting. Thus, Table 6 presents the assessment on how equipped these teachers in the new blended teaching setup. 
Table 6; Adaptive Capacity of Faculty Members on Blended Teaching

\begin{tabular}{|c|c|c|c|c|c|c|}
\hline \multicolumn{2}{|c|}{ Category } & IEd & IIT & IMAGoCS & IAAS & Total \\
\hline \multirow{2}{*}{$\begin{array}{l}\text { Internet } \\
\text { Connection }\end{array}$} & Yes & 31 & 19 & 38 & 7 & 95 \\
\hline & No & 6 & 2 & 6 & 0 & 14 \\
\hline \multirow{2}{*}{$\begin{array}{l}\text { Status of Internet } \\
\text { Connection }\end{array}$} & Good & 15 & 14 & 20 & 3 & 52 \\
\hline & Poor or Intermittent & 22 & 7 & 24 & 4 & 57 \\
\hline \multirow{2}{*}{ Usage of LMS } & Yes & 34 & 20 & 41 & 6 & 101 \\
\hline & No & 3 & 1 & 3 & 1 & 8 \\
\hline \multirow{3}{*}{$\begin{array}{l}\text { Type of Internet } \\
\text { Connection }\end{array}$} & $\begin{array}{l}\text { Prepaid/Postpaid } \\
\text { Mobile Data }\end{array}$ & 10 & 4 & 16 & 3 & 32 \\
\hline & $\begin{array}{c}\text { Home Fiber (PLDT, } \\
\text { Globe, etc) }\end{array}$ & 13 & 7 & 10 & 3 & 33 \\
\hline & $\begin{array}{c}\text { Home DSL (PLDT, } \\
\text { Globe, etc) }\end{array}$ & 7 & 1 & 2 & 0 & 10 \\
\hline Devices Used & $\begin{array}{l}\text { Smartphone, } \\
\text { Laptop }\end{array}$ & 22 & 13 & 32 & 3 & 70 \\
\hline \multirow{2}{*}{$\begin{array}{l}\text { Attendance on } \\
\text { SeminarsRelated } \\
\text { to Blended } \\
\text { Teaching }\end{array}$} & Yes & 28 & 17 & 27 & 7 & 79 \\
\hline & No & 9 & 4 & 17 & 0 & 30 \\
\hline
\end{tabular}

Based on the generated results, it is evident that even faculty members have no access to Internet Connection and experienced poor or intermittent Internet connectivity as presented in Table 6 . While these teachers are expected to have the financial capability to buy their own Internet modem or devices to acquire Internet access, it is their location that has slow to no signal coverage. In the study conducted by Salac and Kim (2016), in terms of Internet connection speed, the Philippines is among the countries with the slowest. The authors added that in 2015, with the National Electric Grid as source of Internet connection of the country, it is distributed in the threelarge islands, yet, not all the islands are connected to this grid such as the Island of Mindanao.
In addition, ranking the most used type of Internet Connection, the combination of using Prepaid/Postpaid Mobile Data, Home Fiber (PLDT, Globe, etc), and Home DSL (PLDT, Globe, etc) ranked the highest, while $64 \%$ of the sampled population of faculty members resort to use smartphone and laptop in blended teaching.

On the usage of the College's learning management system, while $7.3 \%$ are not using the platform, the rest are taking advantage of the features of the said LMS. Other LMS platforms are also utilized by these faculty members, depending on the tasks they give and preferred platform by their students. Moreover, $72 \%$ are in attendance in joining blended teaching related seminars.

\section{Trainings}

Digital tools for asynchronous/synchronouslearning

Pedagogy and andragogy for flexible learning

Assessment and Evaluation

DNSC LMS

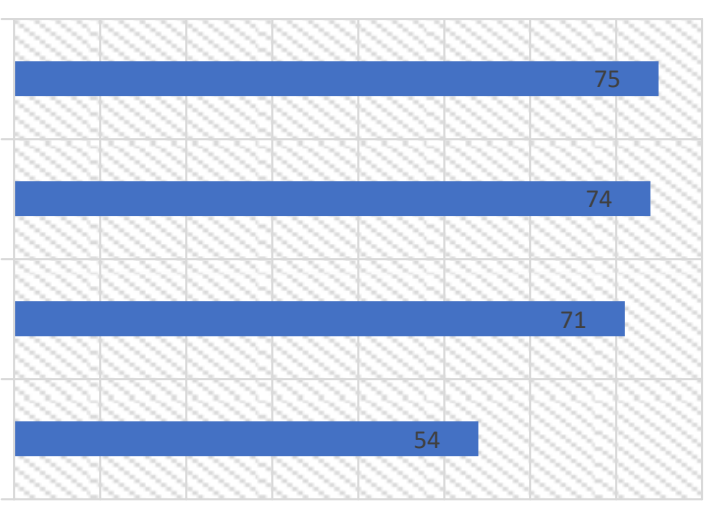

$\begin{array}{lllllllll}0 & 10 & 20 & 30 & 40 & 50 & 60 & 70 & 80\end{array}$

Figure 5: Training related to blended teaching. 
Finally, on asking the faculty members on their preferred seminars and training related to blended teaching, more than half of the teachers picked digital tools for asynchronous/synchronous learning, pedagogy and androgyny for flexible learning, and assessment and evaluation. Moreover, half of the sampled population as projected in Figure 5 showed interest in exploring more the College's LMS. As emphasized by Lockee (2020), teachers are experiencing appreciably different learning and performance contexts related to the mandated shift in professional practice to address continuity of instruction, thus relevant training should be provided in targeting skills and knowledge related to teaching in online and blended environments.

\section{CONCLUSION}

Based on the adaptive capacity of the students on the blended learning set-up with the College, results imply that there are still students who enrolled in this academic year without the basic requirements needed in this new set-up. Although the count is low, yet, no academic journey of any individual learner should be discarded. Thus, it is strongly recommended that before admitting the students in the College, a comprehensive orientation should be provided, along with Parent's Orientation and Consultation on Flexible Learning to prepare the students and parents of the expected teaching and learning set- up, giving them the overview of the learning materials to prepare to avoid any unnecessary burden for the entire duration of the semester. Additionally, literature supports that utilizing television and radio is ineffective in delivering instruction during a pandemic, thus, any approach related to this is not encouraged.

For the blended teaching of the faculty members, it is evident that teachers in the College are adaptive to digital teaching as they showed interest in requesting more training on the platforms and digital tools, which they can utilize in improving teaching performance. In the case of the faculty members with low to no Internet connection, this should be further investigated to check whether the contributing factor still falls in the geographical location of the home address because some programs for the faculty affected by this situation can be initiated.

For further researches in this field of interest, extensive exploration should be undergone to extract the realities of these blended teaching and learning experiences of this academic community. It is strongly suggested that further studies will be conducted on the initiatives done by the administrative body of the College in providing support to the entire academic community in this paradigm shift of delivering instruction. It is hoped that with the results generated in this study, the College will be able to produce resilient learners and teachers to deal with the ever-changing algorithm of teaching and learning in these changing times.

\section{REFERENCES}

[1] Callegaro, M., Manfreda, K. L., \& Vehovar, V. (2015). Web survey methodology. Sage.

[2] Cereno, A. C. C., \& Borlio, J. G. (2021). Surmounting Digital Divide In The Time Of Pandemic By Teacher Education Science Major Students. Surmounting Digital Divide In The Time Of Pandemic ByTeacher Education Science Major Students, 85(1), 5-5.

[3] Feruzi, S. M., \& Li, Y. Application of EdTech in Tanzania: Effectiveness of Radio and Television in Teaching and Learning amid COVID-19 Pandemic.

[4] Lockee, B. B. (2020). Shifting digital, shifting context:(re) considering teacher professional development for online and blended learning in the COVID-19 era. Educational Technology Research and Development, 1-4.

[5] Kabassi, K., Dragonas, I., Ntouzevits, A., Pomonis, T., Papastathopoulos, G., \& Vozaitis, Y.

[6] (2016). Evaluating a learning management system for blended learning in Greek highereducation. SpringerPlus, 5(1), 101.

[7] Niyigena, J. P., Jiang, Q., Ziou, D., Shaw, R. S., \& Hasan, A. S. M. (2020). Modeling the

[8] Measurements of the Determinants of ICT Fluency and Evolution of Digital Divide Among Students in Developing Countries-East Africa Case Study. Applied Sciences, 10(7), 2613.

[9] Passmore, D. L., \& Baker, R. M. (2005). Sampling strategies and power analysis. Research in organizations: Foundations and methods of inquiry, 45-56

[10] Park, K., Park, N., Heo, W., \& Gustafson, K. (2019). What Prompts College Students to Participate in Online Surveys?. International Education Studies, 12(1), 69.

[11] Reyes, M. R. RISK FACTORS OF INTERNET GAMING AMONG FILIPINO STUDENTS.

[12] Salac, R. A., \& Kim, Y. S. (2016). A Study on the Internet connectivity in the Philippines. Asia Pacific Journal of Business Review, 1(1), 67-88.

[13] Vishkaie, R. (2020). The pandemic, war, and sanctions: Building resilience for the digital divide in education. Interactions, 27(4), 36-37.

[14] Vegas, E. (2020). What can COVID-19 teach us about strengthening education systems? Retrieved 8 October 2020, from https://www.brookings.edu/blog/education-plusdevelopment/2020/04/09/what-can-covid-19-teach-us-aboutstrengthening-education- systems/

[15] Volchenkova, K., Bryan, T., \& Shestakova, L. (2016). A centre for academic writing at South

[16] Ural State University: Which model to choose. In 8th International Conference on Education and New Learning Technologies (EDULEARN) (pp. 299-307).

[17] Wibowo, T. O., Udasmoro, W., \& Noviani, R. (2020). Understanding New Consumption Sites of Internet Cafe in Yogyakarta, Indonesia. Jurnal Ilmu Sosial dan Ilmu Politik, 23(3), 237- 249.

[18] Yarbrough, S., Haas, B., Northam, S., Duke, G., \& Wieck, K. L. (2016). Role overload theory as framework for nurse educators to optimize graduate students' learning environment. Journal of Nursing Education and Practice, 6(12), 105-112.

[19] Zayapragassarazan, Z. (2020). COVID-19: Strategies for Online Engagement of Remote Learners. F1000Research, 9. 


\section{SURVEY QUESTIONNAIRE FOR FLEXIBLE LEARNING (STUDENTS)}

Madayaw! This survey is about your learning capacity during this new normal. Please answer each question with all honesty. For short responses item, please follow the format and write in CAPITAL LETTERS. Your response for this survey would be a great help for us to make adjustments on how can we meet both ends. Thank you for sharing your time.

Data Privacy Consent

In accordance with RA 10173 or Data Privacy Act of 2012, I consent to the following terms and conditions on the collection, use, processing and disclosure of my personal data:

I am aware that the Davao del Norte State College has collected and stored my personal data upon accomplishment of this form.

I express my consent for the Davao del Norte State College to collect, store my personal information.

I hereby affirm my right to be informed, object to processing, access, and rectify and to suspend or withdraw my personal data pursuant to the provisions of the RA 10173 and its implementing rules and regulations.

By clicking the Next button below, I warrant that I have read, understood all of the above provisions, and agreed with its full implementation.

FULL NAME (LAST NAME, FIRST NAME, MIDDLE INITIAL.) *

Your answer

Contact Number*

Your answer

Functional Email Address *

Your answer

City/Municipality *

Choose

Complete Address (CITY/MUNICIPALITY, BARANGAY eg. PANABO CITY, NEW VISAYAS) *

Your answer

Institute $*$

Choose

Course *

Choose

Year Level *

Choose

Do you have electricity at home? $*$

Yes

None

Other: 
Do you have Television at home? $*$

Yes

None

Other:

Do you have transistor radio (AM/FM) at home? *

Yes

No

Do you have internet connection at home? *

Yes

No

Other:

What type of internet connection do you use for online/virtual learning? (Choose all that applies) *

Prepaid/Postpaid Mobile Data

Home DSL (PLDT, Globe, etc)

Home Fiber (PLDT, Globe, etc)

Wireless Home Broadband (PLDT, Globe, etc)

Internet Cafe/ PisoNet

None

Other:

What devices are available at home that you can use for learning? (Choose all that applies) *

Smartphone

Laptop

Personal computer

Tablet

None

Other:

What is the status of your internet connectivity? $*$

Good

Poor or intermittent

No internet connectivity

What learning modality did you experience in your classes for this 1st Semester S.Y. 2020-2021? *

Choose 
Have you already used the DNSC Learning Management System (LMS)? *

Yes

No

What features of DNSC LMS have you already used? (Choose all that applies) *

Topics and Lessons

Assessments (Assignments and Quizzes)

Class Announcement

Enrollment of Students

Online Forums and Surveys

None

Other:

What other LMS have you used? *

Google Classroom

Schoology

Edmodo

Other:

What digital technologies that your teachers used in the conduct of synchronous/live/real-time virtual sessions? (Choose all that applies) $*$

Zoom Cloud Meeting Application

Google Meet

Google Classroom

Edmodo

Schoology

Discord Server

Facebook Messenger (Chat/Call)

Telephone call

SMS or Text Messages

None

Other:

What digital technologies your teachers used in the conduct of asynchronous/not live/not real time virtual sessions? (Choose all that applies) *

DNSC-Learning Management System (DNSC-LMS)

Google Classroom

Edmodo 
Schoology

Discord Server

Facebook Messenger (Chat/Call)

Facebook Group/Page

Email

SMS or Text Messages

Telephone call

None

Other:

\section{SURVEY QUESTIONNAIRE ON FLEXIBLE LEARNING FOR DNSC FACULTY}

Madayaw! This survey is about your teaching capacity during this new normal. Please answer each question with all honesty. For short responses item, please follow the format and write in CAPITAL LETTERS. Your response for this survey would be a great help for us to make adjustments on how can we meet both ends. Thank you for sharing your time.

\section{Data Privacy Consent}

In accordance with RA 10173 or Data Privacy Act of 2012, I consent to the following terms and conditions on the collection, use, processing and disclosure of my personal data:

I am aware that the Davao del Norte State College has collected and stored my personal data upon accomplishment of this form.

I express my consent for the Davao del Norte State College to collect, store my personal information.

I hereby affirm my right to be informed, object to processing, access, and rectify and to suspend or withdraw my personal data pursuant to the provisions of the RA 10173 and its implementing rules and regulations.

By clicking the Next button below, I warrant that I have read, understood all of the above provisions, and agreed with its full implementation.

FULL NAME (LAST NAME, FIRST NAME, MIDDLE INITIAL) *

Institute *

IAAS (Institute of Aquatic and Applied Sciences)

Department *

Disaster, Resiliency Management

Employment Status *

Temporary

Permanent

Contract of Service

Part Time

Other: 
How many years have you been in the service? *

Do you have internet connection at home? *

Yes

No

Other:

What type of internet connection do you use for online teaching/virtual classes? (Choose all that applies) * Prepaid/Postpaid Mobile Data

Home DSL (PLDT, Globe, etc)

Home Fiber (PLDT, Globe, etc)

Wireless Home Broadband (PLDT, Globe, etc)

Internet Cafe/ PisoNet

None

Other:

What devices are available at home that you can use for teaching? (Choose all that applies) *

Smartphone

Laptop

Personal computer

Tablet

None

Other:

What is the status of your internet connectivity? $*$

Good

Poor or intermittent

No internet connectivity

Other:

Have you already used DNSC Learning Management System (LMS)? *

Yes

No

Other: 
What features of DNSC LMS have you already used? (Choose all that applies) *

Topics and Lessons

Assessments (Assignments and Quizzes)

Class Announcement

Enrollment of Students

Question Bank

Online Forums and Surveys

None

Other:

What other LMS have you used?

Google Classroom

Schoology

Edmodo

Other:

What digital technologies that you used to conduct synchronous/live/real-time virtual sessions? (Choose all that applies) * Zoom Cloud Meeting Application

Google Meet

Facebook Video Call

Google Classroom

Edmodo

Schoology

Discord Server

Facebook Messenger (Chat/Call)

Telephone call

SMS or Text Messages

None

Other:

What digital technologies that you used to conduct asynchronous/not live virtual sessions? (Choose all that applies) *

DNSC-Learning Management System (DNSC-LMS)

Google Classroom

Edmodo

Schoology

Discord Server

Facebook Messenger (Chat/Call) 
Facebook Group/Page

Email

SMS or Text Messages

Telephone call

None

Other:

Have you attended seminar/workshop/webinar related to flexible Learning? *

Yes

No

Other:

If yes, list down the title of seminar/workshop/webinar attended. *

Your answer

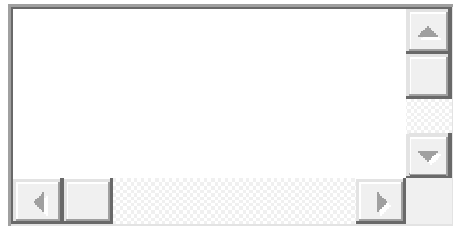

What other trainings do you need related to flexible learning? *

Pedagogy and andragogy for flexible learning

Digital tools for asynchronous/synchronous learning

Assessment and Evaluation

DNSC LMS

Other: 